\title{
ЗЛОВЖИВАННЯ ПРОЦЕСУАЛЬНИМИ ПРАВАМИ У ЦИВІЛЬНОМУ СУДОЧИНСТВІ: ОКРЕМІ ПИТАННЯ
}

Андрієнко І. С.

У науковій статmі досліджено сутність та юридичну природу дефініції «зловживання процесуальним правом». Проаналізовано окремі новели процесуального законодавства, що передбачають заборону зловживання процесуальними правами та встановлюють відповідальність за такі діi. Зроблено висновки про необхідність визначення чітких критеріїв, на підставі яких дії учасників судового процесу можуть визначатися як зловживання процесуальними правами.

Ключові слова: зловживання правом, зловживання процесуальними правами, цивільне судочинство, цивільне процесуальне право.

В научной статье исследованы сущность и юридическая природа дефиниции «злоупотребление процессуальным правом». Проанализированы отдельные новеллы процессуального законодательства, предусматривающие запрет злоупотребления процессуальными правами и устанавливающие ответственность за такие действия. Сделаны выводы о необходимости определения четких критериев, на основании которых действия участников судебного процесса могут определяться как злоупотребления процессуальными правами.

Ключевые слова: злоупотребление правом, злоупотребление процессуальными правами, гражданское судопроизводство, гражданское процессуальное право.

The scientific article investigates the nature and legal nature of the definition of abuse of procedural law. It is noted that the civil procedural code of Ukraine for the first time among the principles of civil justice enshrined the provision on the inadmissibility of abuse of procedural rights, identified the actions of persons who could be qualified as abuse, and also provided a mechanism to combat such a negative phenomenon. The current legal doctrine lacks a single, unified approach to the definition of "abuse of law". What remains to be discussed is the interpretation of the concept of "abuse of law", which implies a number of concepts developed in this direction.

It is also noted that the science of procedural law does not always identify the institution of abuse of law with the concept of "abuse of procedural rights". Attention is drawn to the concept of abuse of procedural rights as a subjective and evaluative concept. From the standpoint of individual authors, abuse of the right should be regarded as a procedural offense solely on condition that the other party to the case establishes a causeand-effect relationship between the abuse and the harm caused (identification of certain risks).

It is noted that a significant step in the reform of the modern judicial system of Ukraine was the consolidation in the new version of the CPC of Ukraine of the provisions prohibiting abuse of procedural rights by the participants of civil proceedings and establishing responsibility for such actions.

At the same time, some of the provisions in the legislation on the qualification of abuse appear to be rather controversial and ambiguous.

Андрієнко І. С., 2019
Attention is drawn to the norms that have received the most criticism among professionals who treat abuses of procedural rights, such as filing a knowingly unsubstantiated claim, a claim in the absence of the subject matter of the dispute, or in a clearly artificial dispute. Also, the absence of a legislative conceptual apparatus can cause problems of practical content.

It is concluded that clear criteria should be defined on the basis of which actions by litigants can be defined as abuse of procedural rights, since, in some cases, the boundary between abuse of law and good faith and reasonable behavior is illusory, which in turn can lead to harmlessness. implications for process participants. The following questions need further clarification: defining the principles that make it possible to consider the claim deliberately unfounded; determination of principles when a complaint, statement, petition is to be left without consideration or return; clear measures to prevent abuse of procedural rights by the court.

Key words: abuse of law; abuse of procedural rights; civil proceedings; civil procedural law.

Постановка проблеми та їі актуальність. Проблема зловживання процесуальними правами була і залишається доволі актуальною для вітчизняної науки та практики, адже правильний і своєчасний розгляд і вирішення цивільних справ в умовах процесуальної недобросовісності стає вкрай складним завданням.

Цивільний процесуальний кодекс України у новій редакції вперше серед основних засад цивільного судочинства закріпив положення про неприпустимість зловживання процесуальними правами, визначив дії осіб, що можуть бути кваліфіковані як зловживання, а також передбачив механізм боротьби із таким негативним явищем. Донедавна суд був доволі обмежений у можливостях виливу на недобросовісну поведінку учасників процесу, а отже, законодавче врегулювання питання заборони зловживання процесуальними правами надасть можливість забезпечити дисципліну учасників процесу та сприятиме правильному та своєчасному розгляду і вирішенню цивільних справ.

Аналіз останніх досліджень і публікацій. Проблема зловживання процесуальними правами $є$ однією із найбільш дискусійних у правовій науці. Дослідниками даного явища свого часу були такі вчені-процесуалісти, як М.М. Агарков, В.В. Бутнєв, С.С. Бичкова, М.Л. Гальперін, В.В. Комаров, Д.Д. Луспеник, С.Я. Фурса, М.Й. Штефан, А.В. Юдін та інші. Праці фахівців торкалися таких теоретичних та практичних аспектів, як визначення юридичної природи зловживання процесуальними правами, проведення їх диференціації, з'ясування особливостей певних способів зловживання, визначення форм цивільної процесуальної відповідальності за такі порушення тощо. Водночас окремі новели законодавства викликали дискусію серед фахівців теорії та практики, а тому потребують детального вивчення та дослідження. 
Метою даного дослідження $\epsilon$ аналіз наявних у правовій доктрині поглядів на сутність категорії зловживання процесуальним правом, а також новели цивільного процесуального законодавства у даному аспекті.

Виклад основного матеріалу. Зловживання правом завжди було і дотепер залишається невід'ємним атрибутом функціонування права. Про зловживання процесуальними правами згадувалось ще за часів римського права, за якого передбачалися заходи протидії поведінці осіб, що безпідставно пред'являли позови або безпідставно заперечували проти них.

Сам термін «зловживання правом» вперше з'явився у законодавстві Швейцарії, а конституційна заборона зловживання правом вперше була закріплена у пам'ятці конституційного права Франції - Декларації прав людини і громадянина 1789 р. [1, с. 12]. Цілісну теорію зловживання суб'єктивними правами виробила французька судова практика в XIX ст., базуючись на нормах права про відповідальність за збиток, хоча в Цивільному кодексі 1804 р. не містилося прямих заборон зловживання правами [2, с. 17].

У сучасній правовій доктрині відсутній єдиний і уніфікований підхід щодо дефініції «зловживання правом». Фахівці виділяють декілька підходів до характеристики даного поняття. Зокрема, прибічники першого підходу (М.М. Агарков, М.С. Малеїн, В.А. Рясенцев тощо) взагалі заперечують існування такої категорії, як «зловживання правом», оскільки правомочність здійснювати право на заподіяння шкоди іншим особам не входить до змісту суб'єктивного права, а тому здійснення права не може бути протиправним. Свого часу М.М. Агарков заявляв, що здійснення права взагалі не може бути протиправним, тому що дії, які називаються зловживанням правом, насправді здійснюються за межами права [3, с. 427].

Інший підхід не заперечує існування категорії «зловживання правом», адже зловживання правом може існувати та передбачає такі відносини, де уповноважений суб'єкт допускає недозволене використання свого права, але при цьому завжди спирається на своє суб'єктивне право. Прибічники даного підходу зазначають, що у правовій доктрині існують ситуації, коли особа здійснює своє суб'єктивне право, формально не порушуючи юридичних заборон, але завдає шкоди суспільним або особистим інтересам іншої особи [4].

Проте дискусійним залишається саме трактування поняття «зловживання правом», що передбачає низку концепцій, вироблених в даному напрямі. Окрім розгляду зловживання правом через реалізацію суб'єктивних прав, існує концепція форми здійснення права всупереч його призначенню, меті, соціальній функції чи інтересам інших суб'єктів, за допомогою якої спричиняється шкода іншим учасникам суспільних відносин. Все більшого розголосу набуває концепція, за якою зловживання правом трактується як різновид правової поведінки. Також зловживання правом розглядають як особливий вид правопорушень, що вчиняються уповноваженою особою при здійсненні нею належного їй права. У рамках концепції зловживання правом шляхом перевищення права та його меж визначено намір заподіяти шкоду, зневагу до суспільних інтересів.

Окремо слід зазначити, що наука процесуального права не завжди ототожнює інститут зловживання правом із поняттям «зловживання процесуальними правами». Існує думка, згідно з якою процесуальна галузь заснована на тому, що всі процесуальні дії, умови та порядок здійснення кожної з них повинні бути визначені законодавцем, тому сама можливість для зловживання судовими процесуальним правами не має під собою жодного підґрунтя.

Згідно з іншою думкою інститут зловживання правами тлумачиться як такий, що об'єктивно зумовлений і цілком властивий процесуальному праву. На думку $€$.В. Васьковського, щоб з'ясувати зміст поняття «зловживання правом», необхідно суть та завдання процесу взяти за відправну точку. Водночас зловживання процесуальним правом слід розглядати як неприпустиме здійснення права, що спрямоване проти правильного і своєчасного розгляду та вирішення справи або призводить до вкрай несприятливих результатів для іншої сторони [5, с. 666].

Подібного підходу у своїх працях дотримується А. Юдін, який під зловживанням процесуальними правами розуміє особливу форму громадянського процесуального правопорушення, а саме умисні недобросовісні дії учасників цивільного процесу, що супроводжуються порушенням умов здійснення суб'єктивних процесуальних прав і здійснюються лише з видимістю реалізації таких прав, пов'язані з обманом щодо відомих обставин справи, з метою обмеження можливості реалізації або порушення прав інших осіб, які беруть участь у справі, а також з метою перешкоджання діяльності суду з правильного і своєчасного розгляду і вирішення цивільної справи, що тягнуть застосування заходів цивільного процесуального примусу [6, с. 56-58].

Цікавою вбачається концепція, за якої зловживання процесуальними правами розглядається як суб'єктивне та оцінне поняття. 3 позиції окремих авторів зловживання правом має розглядатися як процесуальне правопорушення виключно за умови встановлення причино-наслідкового зв'язку між зловживанням та завданою шкодою (певними ризиками) іншому учаснику справи. Тобто зловживання процесуальним правом як особливий різновид цивільного процесуального правопорушення полягає в порушенні умов належної реалізації суб'єктивних цивільних процесуальних прав іншими учасниками справи [7].

Неоднозначне сприйняття даного правового явища зумовлює потребу у чіткому визначенні його на законодавчому рівні. У цьому аспекті пріоритетного значення набувають норми міжнародного законодавства у цій сфері. Зокрема, ст. 17 Конвенції про захист прав і основних свобод людини 1950 року зловживання правом визначає як діяльність або дії, спрямовані на скасування прав і свобод, визнаних у Конвенції, або на їх обмеження у більшому обсязі, ніж це перебачено у Конвенції.

Європейський Суд з прав людини під зловживанням правом (як матеріальним, так і процесуальним) розуміє таке його використання, яке спрямоване на боротьбу із закладеним у ньому позитивним регулятивним потенціалом, в тому числі, що суперечить принципу правової визначеності.

Водночас існує велика ймовірність змішування категорій «зловживання процесуальним правом» $\mathbf{i}$ «реалізація процесуальних прав». Зокрема, у низці випадків Європейський Суд з прав людини у свої рішеннях зазначав, що подання до суду клопотань про відкладення судових засідань на тривалий термін з причини хвороби 
сторони, неодноразова зміна заявлених вимог не свідчить про зловживання правами [8, с. 267].

Вагомим кроком на шляху реформування сучасної судової системи України стало закріплення у новій редакції ЦПК України положень, що забороняють зловживання процесуальними правами учасниками цивільного процесу та встановлюють відповідальність за такі дії.

Також процесуальний закон (ст. 44 ЦПК України) вперше закріпив дефініцію «зловживання процесуальними правами». Таке зловживання слід розуміти як дії, що суперечать завданню цивільного судочинства. Завданням цивільного судочинства $€$ справедливий, неупереджений та своєчасний розгляд i вирішення цивільних справ з метою ефективного захисту порушених, невизнаних або оскаржуваних прав, свобод чи інтересів фізичних осіб, прав та інтересів юридичних осіб, інтересів держави (ст. 2 цПК України).

Розширене тлумачення поняття «зловживання процесуальними правами» надане Верховним Судом, який у своїй практиці розглядає зловживання як особливий різновид цивільного процесуального правопорушення, що полягає у зловживанні процесуальними правами, за якого відбувається порушення умов реалізації суб'єктивних цивільних процесуальних прав, і визначається як поведінка, що перевищує або порушує межі здійснення суб'єктивних прав (ухвала ВС від 6.09.2018, справа № 552/2378/17).

Залежно від конкретних обставин справи до дій, що можуть бути кваліфіковані як зловживання, суд може віднести такі: подання скарги на судове рішення, яке не підлягає оскарженню, не $є$ чинним або дія якого закінчилася; подання клопотання (заяви) для вирішення питання, яке вже вирішене судом; подання декількох однакових позовів з метою маніпуляції автоматизованим розподілом справ; необґрунтоване або штучне об'єднання позовних вимог задля зміни підсудності тощо. Тобто можна дійти висновку, що зазначений перелік дій підлягає розширеному тлумаченню і буде оцінюватися судом у кожній окремій ситуації.

На думку А. Штефана, іншими випадками недобросовісної процесуальної поведінки, добре відомими у судовій практиці, $\epsilon$ затягування строків розгляду справи та неявка в судове засідання з усіх можливих причин, коли зацікавлена особа регулярно перебуває у відпустці, відрядженні чи на лікарняному, а також таке застосування інституту забезпечення позову, коли дійсною метою вжиття тих чи інших заходів $є$ створення несприятливого становища для відповідача чи навіть завдання йому шкоди [9, с. 64].

Важливо зазначити, що окремі положення законодавства щодо кваліфікації зловживань видаються доволі суперечливими та неоднозначними.

У літературі особливої критики зазнала норма, що відносить до зловживань процесуальними правами такі дії, як подання завідомо безпідставного позову, позову за відсутності предмета спору або у спорі, який має очевидно штучний характер (п. 3 ч. 2 ст. 44 ЦПК). Слід погодитись, що вказана норма $є$ прямим порушенням права на судовий захист, гарантованого Конституцією України (ст. 55), а також Конвенцією про захист прав людини і основоположних свобод. Зокрема, ч. 1 ст. 6 Конвенції передбачає право кожного на справедливий і публічний розгляд справи упродовж розумного строку незалежним і безстороннім судом, встановленим законом, який вирішить спір щодо прав та обов'язків цивільного характеру. Європейський суд з прав людини тлумачить це положення буквально як гарантію справедливого судочинства, одним з аспектів якого є доступ до суду. Так, у справі “Bellet v. France” зазначається, що рівень доступу, наданий національним законодавством, має бути достатнім для забезпечення права особи на суд з огляду на принцип верховенства права в демократичному суспільстві. Щоб доступ був ефективним, особа повинна мати чітку практичну можливість оскаржити дії, які становлять втручання у їі права.

Водночас відсутність законодавчо закріпленого понятійного апарату може викликати проблеми практичного змісту. Так, категорії «завідомо безпідставний позов» та «позов, який має штучний характер» потребують чіткого визначення, а також вироблення критеріїв віднесення різних вимог до безпідставних або штучних.

С. Бичкова вважає, що суд має встановлювати у кожному конкретному випадку те, чи добросовісно учасники цивільного процесу здійснюють свої процесуальні права. Межа між добросовісним використанням своїх цивільних процесуальних прав і зловживання ними $\epsilon$ доволі умовною, і для виявлення факту зловживання правом однієї лише внутрішньої впевненості судді недостатньо, потрібні конкретні докази, що підтвердять відповідний факт [10, с. 89].

Отже, щоб надати оцінку процесуальному документу, суд має дослідити матеріали в сукупності та оцінити докази, а така можливість на стадії прийняття позовної заяви у суду відсутня, оскільки суд здійснює оцінку доказів виключно в нарадчій кімнаті [11]. Фахівці зазначають оцінний та суб'єктивний характер понять «завідомо безпідставний позов», «позов, який має штучний характер», що на практиці може призвести до ситуації, за якої один позов буде визнаватись судом як зловживання процесуальним правом, а інший і аналогічний позов розглядатиметься судом лише залежно від складу суду, на який такий позов буде розподілений.

Додаткової конкретизації та роз'яснення потребує і положення ч. 9 ст. 141, згідно з яким суд має право покласти на сторону судові витрати повністю або частково незалежно від результатів вирішення спору у разі процесуального зловживання. У літературі виказується точка зору, що такий підхід законодавця створює певну правову колізію із п. 12 ч. 3 ст. 2 (однією з основних засад цивільного судочинства $\epsilon$ відшкодування судових витрат сторони, на користь якої ухвалене судове рішення) та ч. 1, 2 ст. 141 (судовий збір покладається на сторони пропорційно до розміру задоволених позовних вимог [10, с. 89]). 3 огляду на це виходить, що штрафи за зловживання правами включаються до складу судових витрат, однак штрафи за зловживання правами не входять до складу судових витрат, тому фактично виникає спір всередині спору.

Не дуже виваженим $\epsilon$ i запровадження процесуальної відповідальності (санкції) за подання скарги, заяви, клопотання, що кваліфікується як зловживання правом у вигляді залишення без розгляду або їх повернення. В одному випадку відбувається порушення права особи на судовий захист. В іншому випадку особа має право повторного звернення до суду з тією ж вимогою, що повністю нівелює мету припинення зловживання правом та добросовісне виконання процесуальних обов'язків. 
Отже, вважається виваженою необхідність визначення чіткихкритеріїв, напідставі якихдіїучасниківсудового процесу можуть вважатися зловживаннями процесуальними правами, оскільки в деяких випадках межа між зловживанням правом та добросовісною і розумною поведінкою $є$ доволі ілюзорною, що в свою чергу може призвести до безпідставних негативних наслідків для учасників процесу. На думку фахівців, додаткового роз'яснення потребують такі питання: визначення принципів, які дозволяють вважати позов завідомо безпідставним; визначення принципів, коли скарга, заява, клопотання підлягає залишенню без розгляду або поверненню; з'ясування заходів для запобігання зловживанню процесуальними правами з боку суду [12].

Висновки. Отже, закріплення у цивільному процесуальному законодавстві заборони зловживання процесуальними правами є суттєвим кроком на шляху до підвищення ефективності цивільного процесу. Водночас слід звернути увагу на визначеність та характеристику дій, що можуть бути кваліфіковані як зловживання процесуальними правами, з метою їх відповідності національному та міжнародному законодавству, а також однаковому тлумаченню норм у правозастосовній практиці.

\section{Література}

1. Рогач О.Я. Зловживання правом: теоретико-правове дослідження : автореф. дис. ... д-ра. юрид. наук : 12.00.01. Київ, 2011. 34 с.

2. Калюжний Р.А., Андрущенко І.Г. Зловживання правом: сутність та шляхи протидії. Бюлетень Міністерства юстиції України. 2006. № 8. С. 16-22.

3. Агарков М.М. Проблема злоупотребления правом в советском гражданском праве. Известия АН СССР, Отделение экономики и права. 1946. № 46. С. 424-436.

\section{Проблеми цивільного та господарського права}

4. Шилов М.Л. До питання про сутність зловживання правом. Український юридичний портал. URL: http: //radnuk. info/statti/249-tioriua-gov/14812-2011-01-19-03-16-54.html.

5. Васьковский Е.В. Курс гражданского процесса : учебник. Т.1. Москва, 1915. С. 666-677.

6. Юдин А.В. Злоупотребление процессуальными правами в гражданском судопроизводстве : дис. ... д-ра юрид. Наук : 12.00.15. Санкт-Петербург, 2009. 537 с.

7. Василина Н. Зловживання процесуальними правами в цивільному судочинстві та нотаріальному процесі. URL: https://sud.ua/ru/news/blog/143080-zlovzhivannyaprotsesualnimi-pravami-v-tsivilnomu-sudochinstvi-tanotarialnomu-protsesi.

8. Петренко В.С. Зловживання процесуальними правами в цивільному судочинстві. Young Scientist. 2016. № 6. С. 265-268.

9. Штефан А. Зловживання цивільними процесуальними правами як юридичний процесуальний факт. Теорія $i$ практика інтелектуальної власності. 2017. № 2. С. 62.

10. Бичкова С. Цивільний процесуальний правовий статус осіб, які беруть участь у справах позовного провадження : монографія. Київ : Атіка. 2011. 420 с.

11. Безнощенко К. Відмова через безпідставність. Закон і бізнес. 2017. URL: http://zib.com.ua/ua/print/ 130179vidpovidalnist_za_zlovzhivannya_procesualnimi.

12. Узагальнення судової практики розгляду судами деяких питань, пов'язаних із зловживанням процесуальними правами: практика застосування новел цивільного процесуального законодавства. URL: https://oda.court.gov.ua/ userfiles/file/sud1590/Zlovgivannya_procesyalnymy_ pravamy.pdf.

Андрієнко І. С., кандидат юридичних наук, доцент, професор кафедри цивільно-правових дисциплін одеського державного університету внутрішніх справ 